\title{
Strengthening The Traditional Markets: An Evidence From Bosowasi Region, South Sulawesi
}

\author{
Syaparuddin, Sari Utami, Jumriani
}

State Islamic Institute of Bone, South Sulawesi, Indonesia safarb135@gmail.com, sary_utm@yahoo.co.id, safar_bone@yahoo.co.id

\begin{abstract}
This research aimed to describe the model of strengthening the traditional markets. It was conducted in the Bosowasi region for six months. The type of this research was a qualitative descriptive one by using a social approach in gathering data and using the theory of social structure, social construction, social change, and planned behavior to analyze the data. The results of this research showed that (1) The modernization and technological development apparently do not necessarily eliminate people's desire to shop in traditional markets, (2) The democratic trade model practiced in traditional markets can actually drive the people's economy, and (3) The innovation, partnership and policies developed in traditional markets can make them existing throughout time without compromising the needs of future generations. These results served as the basis for formulating the model of strengthening traditional markets and this model was called the "BSWS Model". This model can make the traditional markets orderly, safe, clean and healthy, can make them competitive with the modern retailers, can improve services to the community, and can make them as a driving wheel of the regional economy.
\end{abstract}

Keyword:Bosowasi; economic foundation; social structure; traditional market.

Permalink/DOI: bttps://doi.org/10.18326/infsl3.v14i2. 221-248 


\section{Introduction}

The presence of modern markets (malls and minimarkets) in the era of the global economy seems to make the presence of traditional markets in the Bosowasi Region increasingly pressured. In addition to being physically unable to compete with modern markets, also their trademark as markets that provide cheap goods are already unpopular. Traditional markets that are unique and identical to markets that allow bargaining of goods are also not attractive, because at present modern retailers, such as Alfamart and Indomart, offer goods at low prices, even at discount prices. As a result, consumers will forget the existence of traditional markets. However, the fact is not like that, based on observations conducted for several traditional markets in the Bosowasi region it showed that the people there were still happy to visit traditional markets to shop, because according to them, the existence of traditional markets was not solely for the economic matters, but also about the issues of space and the social relations, the cultural heritage and realm, as well as the longstanding civilizations with inherent historical values (Observation Results, 2019). It means that the existence of traditional markets is still needed very much by the people in the region, therefore its existence needs to be strengthened.

So far the studies of strengthening traditional markets in the specification of sustainable development with a social approach have not been enough attention from the experts. However, there were studies found that discussed the strengthening of traditional markets with different specifications from this research, they were conducted by Sabaruddin (2016) and Aliyah (2014 and 2017). Sabaruddin's study (2016) discussed the support of traditional and modern markets in strengthening Indonesia's diplomacy and trade policy. While the study conducted by Aliyah (2014) discussed the strengthening of synergies between traditional markets and modern markets. While another study conducted by Aliyah (2017) discussed the strategies to strengthen the role of traditional markets. In addition to the study of strengthening traditional markets, a study which also discussed the sustainable development of traditional markets with different specification from this research was conducted by Farhani (2014). He discussed the sustainable management of traditional markets. 
However, the studies that discuss the strengthening of traditional markets in the specifications of sustainable development have not been specifically done, so this research is here to discuss this, and this is the motivation of this research. It was in the Bosowasi region for several reasons, they are: (1) the Bosowasi region is one of the mainstay regions that was declared in 2015 during the governship of the Governor of South Sulawesi, Syahrul Yasin Lompo, (2) As one of the regions that is used as a center of development in the transportation, agriculture, plantation and tourism sectors, (3) As one of the regions used as a center for the development of superior commodities through technology transfer and utilization of superior seeds, (4) As one of the regions that is prioritized for the acceleration and structuring of infrastructure development such as roads, agriculture, plantations, and the development of business centers, (5) Relations between the four regions in various aspects are very strong from the past until now, (6) The social structure is very thick with the authority of the Buginese culture, and (7) Traditional markets in the region are considered as the main foundation of the people's economy (Observation, 2019).

Based on the above motivation, this research tries to formulate a strengthening model for traditional markets in the Bosowasi region to meet the needs of the present generation without sacrificing the needs of future generations in this global economic era. In line with that, three assumptions can be proposed in this research, they are: (1) Modernization and technological development are believed not to eliminate people's desire necessarily to shop in traditional markets, (2) The democratic trade model practiced in traditional markets is believed to be able to move the economy of the people., and (3) Innovations, partnerships, and policies that are made in traditional markets are believed to be able to make them exist all the time without sacrificing the needs of future generations.

\section{Methods}

To get a comprehensive result, this research used a qualitative approach in gathering data. The method used to collect the data were (1) Observation, observing the characteristics of traditional markets in the Bosowasi Region, (2) Interviews, in-depth interviews 
conducted with informants about the contribution of traditional markets to the development of the Bosowasi region, (3) Focus Group Discussion, this methode conducted with the resource persons about strengthening traditional markets for sustainable development in the Bosowasi Region, and (4) Documentation, this methode used to obtain written data related to the characteristics of traditional markets, the contribution of traditional markets to regional development in the Region, and strengthening traditional markets for sustainable development in the Region in general, and specifically in the Bosowasi Region. Whereas in analyzing the data collected by the those methods, a social approach was used by looking at economic, social, and environmental aspects, namely the primary data collected from the facts of traditional markets in the Bosowasi Region through observation, interviews and Focus Group Discussion and the secondary data through documentation, then the data were analyzed with social structure theory, social construction theory, social change theory, and Planned Behavior theory. While these theories refered to the assumptions proposed in this research. The results of the analysis served as the basis for drawing conclusions.

\section{Results and Discussion}

\section{The Impact of Modernization and Technological Development}

William F. Ogburn (1922) suggested two things about social change, they are: (1) The cause of change is the dissatisfaction of society because of the social conditions prevailing at the time that affected their personalities, (2) Although each social element has a continuous relationship, however some have changed and some others are still static. The emergence of modern markets and online markets were the forms of changes that occured in the midst of society in the Bosowasi Region (Trade Office of Bone, Soppeng, Wajo and Sinjai Regencies, 2019). These forms of change were forms of social change. Therefore, the existence of a modern market and an online market was greatly affected by the impact on the existence and sustainability of traditional markets in the Bosowasi Region. Modern markets (malls and minimarkets), as a form of modernization, while online markets, as a form of technological development, namely the advancement of information technology. 
As a result of modernization and technological development, traditional markets in the Bosowasi Region are increasingly abandoned by their customers. The exact main cause of that is the proliferation of modern retailers in that region. Shifting patterns of public consumption is one of the results of modernization (Interview, 2019). Referring to the concept of modernization, the people increasingly use their rational thinking and practicality in behavior. So that the people today are more likely to look for something easy, practical and hygienic. In the consumption pattern, people tend to prefer modern retails that are practical and hygienic to traditional markets which tend to be obsolete.

The growth of modern shopping retails in the areas of the Bosowasi Region has weakened the appeal of people to shop in traditional markets. Traditional markets that tend to be outdated and dirty make people, especially young people, reluctant to shop, as well as the issue of prestige and self-esteem (stratification in society) makes the upper classes seldom shop at traditional markets. The phenomenon cannot be denied that the attractiveness of traditional markets has declined. This is due to the poor condition and completeness of traditional market facilities and infrastructure. The highly congested market conditions with the arrangement of merchandise that spilled from the sales plots, the very limited space for corridors, as well as the cramped and dirty atmosphere made the conditions of traditional markets in contrast to the conditions of modern retail retailers. Looking at the plight of traditional markets, they need to to preserve (Observation, 2019).

The data of this research obtained through observation, interviews, and FGD (2019) showed that the economy of people finds its sovereignty as the foundation of the national economy starting from the traditional markets. The existence of the traditional markets is one of the drivers of the economy of people. Traditional markets have become a center of economic and a place of interaction between people at the same time, such as the process of bargaining between buyers and traders who show the characteristics of people, including in the Bosowasi Region, in socializing each other. Besides the existence of traditional markets is the center of real economic circulation for people, also the symbol of harmony and concern for 
citizens. It means that the traditional markets are the artery of the people's economy even as the socio-economic site for them.

In the Bosowasi Region, the preservation of traditional markets is being promoted by local and central government in various forms of policy. Traditional market development is carried out starting from the physical improvement of the market to reaching out to the market management system. Physical improvements include the construction of market facilities and infrastructure, so that they almost resemble modern retailers. Policies in order to protect traditional markets in the Bosowasi Region began to be implemented by each local government in the region. For example by limiting modern retailers spending around traditional markets, and reforming the market bureaucracy system. This is a form of traditional market revitalization done by the local government in the Bosowasi Region (FGD, 2019).

The forms of change that occured in traditional markets as mentioned above, is one form of social changes. According to William F. Ogburn (1922) that social change includes cultural elements both material and immaterial one which emphasized the great influence of the elements of material culture on immaterial elements. The use of technology in traditional markets will affect the pattern of actions of market visitors. For example, the installation of CCTV (closedcircuit television), criminals would be increasingly afraid to commit acts that violate the law. Similarly, the installation of price billboards made traders reluctant to shape the price of goods at will. Traders could not easily raise the price of goods unilaterally (Interview, 2019). The installation of CCTV and billboards in traditional markets will benefit many buyers. This is what makes the main attraction of traditional markets. So that it is hoped that the traditional markets will be able to compete with modern retailers.

As a result of social changes that occured in traditional markets as expressed above, no doubt will fade the entity of the traditional markets themselves. The traditional and substantive nature will slowly change into a nature that emphasizes formal relations as in modern retailers. In the end the changes that occured in traditional markets must go through a thorough study. So that the traditional 
markets can compete with modern retail retailers without losing the essence of the traditional markets themselves.

For Buginese people who live in the Bosowasi region, traditional markets are not just a place for buying and selling, even they are related to the conception of life and social culture. Markets do not merely provide economic activity, but actors can also achieve other goals (Observation, 2019). Thus it can be said that traditional markets can be a place for economic activities, social interaction, and recreational facilities both in the atmosphere of the markets and the typical merchandises. If this is the reality, the traditional markets can be stated that they are the concrete form of social institutions, while the social institutions are the form of social structure. Traditional markets are said to be concrete manifestations of social institutions because in traditional markets there are rules, norms, customs and the like that regulate community needs and have been internalized in their lives, in other words traditional markets are norm systems that have been institutionalized or become institutions in a society. This means that, no matter how devastating the impact of modernization and technological development, the community will never leave the markets that have been built because the markets are the part of their lives unless there is something compelling and there are strong enough reasons that influence them to change so that the markets that were built are abandoned. However, the facts on the ground showed that in the Bosowasi area, the people never leave traditional markets, they only move the location of these markets to other places in the area where they live.

\section{Democratic Trading Model}

Berger and Luckmann (1966) said that reality is built socially, in the sense of individuals in society who have built society, the experience of these individuals cannot be separated from society. Humans as creators of objective social reality through three simultaneous dialectical moments, namely: Externalization, objectification and internalization. At the moment of externalization, the individual tries to adapt to his environment, in the moment of adaptation the means used can be in the form of language or action. In the context of this research, traders see the social reality that traditional markets are 
their livelihoods, whereas buyers see traditional markets as places to shop to meet their needs, they will enter it to trade for traders and shop for buyers (externalization). This moment of externality illustrates the process of adaptation of traders and buyers to traditional markets.

At the moment of objectivation, individuals will try to interact with their environment. In objectivation, the social reality seems to be outside of human beings. It becomes an objective reality, so there are two realities, the subjective reality and the reality beyond the objective self. These realities form an intersubjective network through an institutional process. Institutional is a process to build awareness into action. In the institutionalization process, the values that guide the interpretation of actions have become an inseparable part so that what is realized is what is done. In the context of this research, traders and buyers interact with each other in the form of buying and selling goods at prices agreed on together. In carrying out these transactions they adhere to the norms that are paraded in the traditional markets where they make transactions, so there is an institutionalization process for them to understand and respect one another.

At the moment of internalization, individuals will identify themselves in their environment. Internalization is a moment of withdrawing the social reality into themselves or into the subjective reality. The social reality is in humans and through this the human will identify themselves in their environment. In the context of this research, traders and sellers will always come to the market to trade for traders and to shop for buyers because they already feel a part of the market. If they feel that they are part of a traditional market, they will make transactions in a democratic way, namely transactions that are carried out on the basis of the strength of supply and demand proportionally between sellers and buyers so that they are very difficult to leave the traditional market unless there is a social change happening to them. This is called the democratic trade model practiced in traditional markets.

The data (Observation, Interview, Focus Group Discussion, 2019) of this research show that the democratic trade model that 
is practiced in traditional markets in the Bosowasi Region that the bargaining process is something that will not be found in any modern markets. Because of this, Bosowasi people still go to traditional markets, but also the prices of good in the traditional markets are relatively cheaper, however, if the prices of food increase, they will still be expensive as well. Usually, they are less expensive then those in the modern markets.

Interaction in traditional markets in the Bosowasi Region is also more pleasant, not rigid, there are also no binding provisions from the company to its employees. Usually the boss also directly sells and is assisted by several employees, but there are still no fixed rules. It means that the hospitality and thanks to the customer are not ignored, when the process of transaction takes place and has finished shopping (Interview, 2019).

Even if there are some loyal customers, usually the services provided will be more excited and many jokes are inserted in the conversation. It also becomes a differentiator when shopping at traditional markets. With all the unique characters between traders and buyers, everything merges into one in the buying and selling process (Interview, 2019).

Traditional markets are still the most pleasant shopping places to buy basic necessities such as vegetables, market snacks, and kitchen spices with a distinctive aroma. The market is a place where the sellers and the buyers can meet face to face and dialogue. Payment in cash from the buyer's wallet to the seller, really has a sensation that is never found in any modern markets (Interview, 2019).

Shopping in traditional markets, there are still bargains and friendship prices. This means that buyers who have become customers like relatives, so the seller takes off with a low price as long as there is a difference in price (profit) even though a little. The term that is often used by sellers in traditional markets, namely: It's better to lose money, as long as you get relatives as The philosophy in establishing relationships with customers that the trading transactions in traditional markets are not only the buying and selling process. But also the meeting of buyers and sellers in the 
market and at the same time they exchange the latest information, establish hospitality as part of the rhythm of life, and as social beings who need each other (Interview, 2019).

This is the way of sellers to establish relationships with customers who have often bought their wares. When the relationship of sellers and buyers has been established properly, the trust will be formed among them. Consequently, the price of goods is no longer a determining factor, because the quality and honesty of the seller are preferred.

\section{Innovation, Partnership and Policies}

To explain by macro the strengthening of traditional markets in the Bosowasi Region from the aspects of innovation, partnership, and policies, the theory of social change was used to do the job. The innovation meant here is the process and the results of the development of the utilization of an existing product so that it has a more meaningful value. The innovation process is greatly influenced by technological and scientific advances because both can make it easier to produce something new and different from the previous production. The partnership meant here is to synergize with modern shopping retailers, so that their presence is no longer a threat to small traders, especially in traditional markets, but on the contrary, it will become one of the pillars for fostering more advanced MSMEs (medium, small and micro enterprises). The policies meant here are the policies issued by the central and regional governments regarding the protection and empowerment of traditional markets.

William F. Ogburn (1922) suggested two things about the social change, they are: (1) The cause of change is the dissatisfaction of society because of the social conditions prevailing at the time that affect their personalities, (2) Although every social elements has a continuous relationship, but some has changed and some is still static. Underdevelopment makes the gap among the elements that change very quickly and change slowly. This gap will cause a social shock to the community. The cultural lags illustrate how some cultural elements are lagging behind the changes that originate from creation, discovery and diffusion. Technology, according to Ogburn, changes first, whereas culture changes most recently. In other 
words, we try to pursue technology that is constantly changing by adapting our customs and ways of life to meet technological needs. Technology is causing rapid social change that is now sweeping the world. Changes in technology will be faster than changes in culture, thoughts, beliefs, values, norms that become a tool to regulate human life. Therefore, change often results in social surprises which in turn will lead to new patterns of behavior, despite conflicts with traditional values.

The traditional values that make the traders of traditional markets in the Bosowasi Region static are their unambitious culture, and their belief that sustenance will never be exchanged. If these values are not abandoned, the existence of traditional markets will be threatened by the presence of online markets in their midst. Therefore, they are encouraged to innovate with technology. To do this, social media can be used to market their goods online and is very effective if compared to the offline sales they have made so far in traditional markets in the Bosowasi Region. Social media is very important for promotional purposes, every day many users use social media until an indefinite time. If they want to use social media for the promotion of products and services, they can create an account by providing useful information and of course it must be related to the products and services they are marketing. Social media that are widely used for promotional events are Facebook and Instagram. Currently both of these social media are very popular and are widely used for promotion. Facebook has the most users from all over the world, and Instagram has been able to attract many enthusiasts to use it. Using Facebook also cannot be arbitrary, every social media certainly has a policy that must be followed by its users. To attract many interested people to social media, the information presented must be interesting and useful. No hurry to get a profit, serving followers by providing interesting information and having attractiveness. If you already have a lot of followers, the products and services that will be marketed can already be introduced. This is done to provide maximum service to the community. The maximum service can have a good impact on their business conditions (Focus Group Discussion, 2019).

Another $t$ hreat faced by the traditional markets in the 
Bosowasi Region if the people there still maintain these values, is the development of modern retailers. It seems that this makes the small and micro traders in traditional markets in the region worried about it. They think that the market penetration done by modern retailers through the opening of distribution networks to the subdistrict level can kill traditional markets in the Bosowasi Region as the main distribution channel for micro and small enterprises. They are considered as the last defense of micro, small and medium enterprises that dominate the livelihoods of the lower and middle class people in the Bosowasi Region. Therefore, the existence of traditional markets in the region is a part of the social and economic structure of the Bosowasi people that must be maintained. The local governments in the Bosowasi Region have actually tried to anticipate unhealthy competition between traditional markets and modern retailers. The traditional markets are empowered by changing physical appearance and adding facilities. Only the service model or type of transaction is maintained with a view to maintaining the social relations that arise from the pattern of economic transactions in traditional markets. However, in many cases, modern retailers have advantages in terms of service, clean appearance, complete goods, and low prices. Indeed, the idea of limiting the number of modern retailers in the Bosowasi Region can be done, but they can change their marketing strategies, for example by buying the distribution networks of traditional markets or they use different names for network of traditional markets. This strategy has been carried out in several places and they have succeeded. Therefore, an alternative idea that can be done is to synergize traditional markets with them. If both are synergized, the presence of modern retailers will no longer be a threat to small traders, especially in traditional markets, but on the contrary, they will become one of the pillars for the development of more advanced MSMEs (medium, small and micro enterprises) (Focus Group Discussion, 2019).

To support the above, in order to strengthen the existence of traditional markets in the Bosowasi Region, the policies are needed. The policies are certainly issued by each local government in the Bosowasi Region. The local government policies in the Bosowasi Region regarding the protection and empowerment of traditional 
markets actually were already made, only their implementation are generally considered not effective yet. Specifically, they can be seen from several aspects in evaluating them, they are: The aspect of the possibility of walking is quite effective, the strengthening aspect is quite effective, the aspect of protection is not effective, the supporting aspect is not effective, and the maintenance aspect is not effective. Only two aspects support the implementation of those policies in protecting and empowering traditional markets in the Bosowasi Region, and three other aspects do not support those policies. So in general the policies that have been made by the local governments in the Bosowasi Region in protecting and empowering traditional markets are still ineffective. If so, the policies need to be reviewed in order to be effective in strengthening the existence of traditional markets.

While the micro description of strengthening traditional markets iMSMn the Bosowasi Region from the aspect of innovation, partnership, and policies, the Planned Behavior theory was used to do the job. The Planned Behavior Theory (Ajzen, 1991) is a theory that explains about human behavior. The basic assumption of this theory is that humans behave in a conscious manner and consider all available information. This theory has three main components, they are attitudes, subjective norms and perceived behavioral control. The explanation of these components are: First, belief in behavior that influences attitudes toward behavior. Behavioral beliefs are things that encourage individuals to act. While attitudes toward behavior are individual attitudes towards behavior obtained from the beliefs generated by the behavior. In the context of this research, attitudes towards strengthening the behavior of traders of traditional markets in the Bosowasi Region make them believe that the aspects of innovation and partnership can strengthen the existence and sustainability of traditional markets so they tend to innovate and partner. While the attitude towards the behavior of the central and regional governments in strengthening traditional markets in the Bosowasi Region makes them believe that the strengthening policies issued can make traditional markets in the Bosowasi Region exist and are sustainable, so they tend to issue policies that can strengthen the existence and sustainability of those 
traditional markets.

Second, normative beliefs that influence subjective norms. Normative beliefs are the norm used by people who will influence in decision making. Whereas subjective norms become as individual perceptions of existing socialization to show or not behavior. These subjective norms are synonymous with a person's beliefs about the actions or other people who need, must, or may not conduct behavior, and motivate people to know the other persons. In the context of this research, the traditional market traders' beliefs in their innovation and partnership done, and the central and regional governments' beliefs in their policies, can motivate the people in the Bosowasi Region to come and keep shopping all the time in the traditional markets where they live.

Third, belief control affects the control of perceived behavior. Control of beliefs are personal experiences, or people that will influence individual outcomes. Perceived behavioral control is the belief that individuals have done or have never done certain behaviors. Clever behavioral control and interpreted individual perceptions related to certain behaviors. In the context of this research, perceived behavioral control is the experience of traders of traditional markets in conducting innovations and partnerships, and policies issued by the government. The behavioral control turned out to be able to make people who visit traditional markets in the Bosowasi Region feel at home and feel comfortable shopping, so that they will come back again to shop there.

If so, it can be stated that the innovation and partnership carried out, as well as policies issued to strengthen the existence of traditional markets in the Bosowasi Region are believed to make people who visit these traditional markets feel at home and feel comfortable shopping, so this makes them exist. all time and also do not sacrifice the needs of future generations.

\section{Formulating a Model for Strengthening Traditional Markets}

Based on the results of the discussion of those assumptions above, the formulation of a model for strengthening traditional markets in the Bosowasi Region can be revealed that the community views traditional markets in the Bosowasi Region as a social reality. 
Because it is a social reality, it is considered as a form of social structure, namely as a social institution. The concrete forms of social institutions such as rules, norms, customs and the like that regulate social needs, have been internalized in their lives, in other words traditional markets are norm systems that have institutionalized or become institutional in a society. On this basis, the traditional markets are seen as the foundation of the people's economy. Activities that occur in the markets through three moments: (1) externalization, at this moment the community, traders and buyers see the traditional markets as a social reality, because of that, they adapt to the markets, i.e. they enter the market to carry out activities, (2) objectivation, at this moment, traders and buyers carry out activities, i.e. they interact with one another, for example transactions of buying and selling goods at certain prices directly and proportionally without any pressure, (3) internalization, at this moment, after repeated times, traders and buyers make transactions, then they see themselves as part of the markets. Because they see as part of the markets, they are one big family in the markets. If so, then the economy they build is believed that ic can increase, and even can develop rapidly. This is called the democratic trade model.

Because modernization and technological development from time to time can have a bad impact on traditional markets in terms of economic, social, and environment, so that the traditional market will be abandoned by the community. If so, it can be stated that the traditional market is changing. Changes in traditional markets are one form of social change. Therefore, strengthening needs to be done. Strengthening is outlined in the form of planning (strengthening intentions) and actions (strengthening behavior). Strengthening is carried out through three moments: (1) behavioral beliefs, at this moment, traders believe that the innovation and partnership they carry out are strengthening behaviors for traditional markets. At the same time, the central and regional government also believed that the policies issued were strengthening behaviors for traditional markets. This moment is believed that it can make the markets as optional and sustainable markets without sacrificing the needs of future generations, (2) nomative beliefs, at this moment, traders believe that every innovation and partnership they do, and every policy 
issued by the central and regional government can motivate people to always come to traditional markets to fulfill their lives, and (3) confidence in control, at this moment, the experience of traditional market traders in innovation and partnership, and policies issued by the government were able to make people visiting traditional markets, feel at home and feel comfortable shopping, so they will come back again to shop there.

This model is called the BSWS (Bone, Soppeng, Wajo, Sinjai) model because the data were obtained in the Bosowasi Region. The BSWS model can be presented in the figure 1 below:

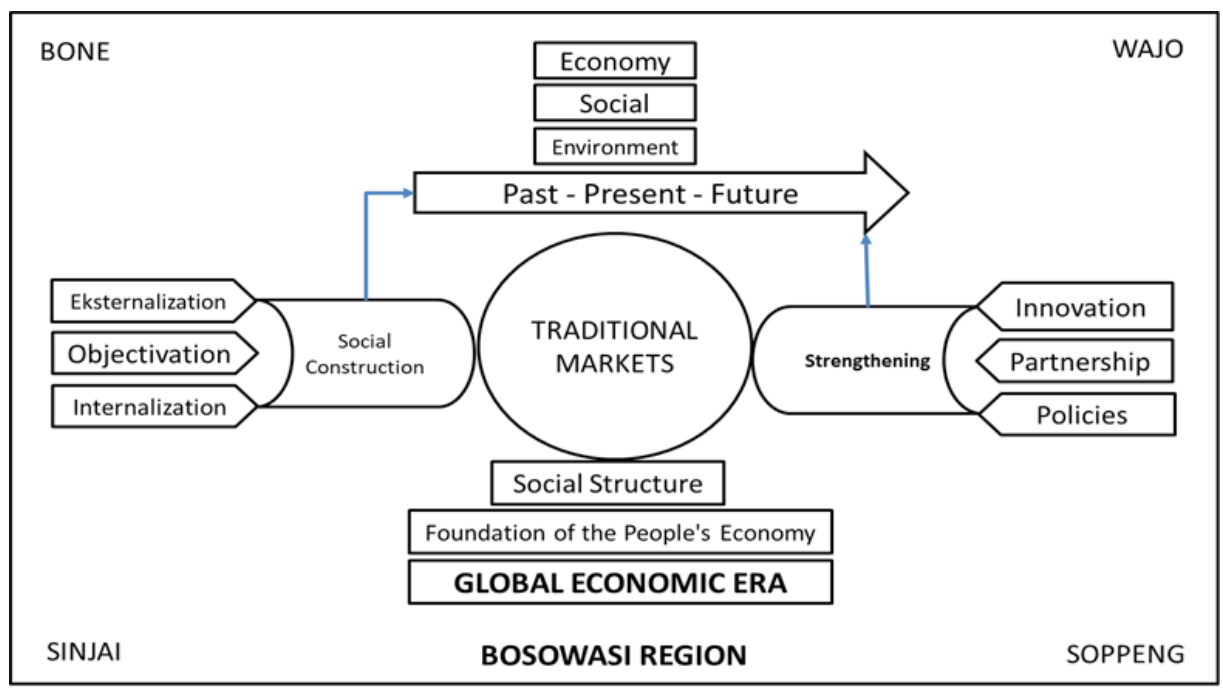

Figure 1: BSWS Model (The Model for Strengthening Traditional Markets)

Source: obtained from primary data, 2019.

This model needs to be tested to find out how it works, whether it can be used or not in strengthening traditional markets sustainably. The basis of decision making on the assessment of the sustainable strengthening of the BSWS model above is stated to be an increase or decrease in score. The description can be presented as below:

First, To find out whether the strengthening is successful or not (the score of $\mathrm{SSt}_{3 \mathrm{~m}}$ goes up or down), use the formula below: 
$-\mathrm{SSt}_{3 \mathrm{~m}}=\left(\mathrm{R}_{3 \mathrm{~m}}-\mathrm{R}_{3 \mathrm{~m}-3} / \mathrm{R}_{3 \mathrm{~m}-3}\right) \times 100 \%$

- $\mathrm{SSt}_{3 \mathrm{~m}}=$ Sustainable strengthening in percentage (\%)

$-\mathrm{R}_{3 \mathrm{~m}}=$ Market retribution revenue for three months

- $\mathrm{R}_{3 \mathrm{~m}-3}=$ Market retribution revenue in the previous three months Simulation example:

The data example owned for the past 5 quarters (15 months), can be presented in table 1 below:

Table 1. Simulation Data on Market Retribution Revenue Per Quarter

\begin{tabular}{ccc}
\hline No. & Quarter (2018-2019) & $\begin{array}{c}\text { Market Retribution Revenue } \\
\text { (Million in IDR) }\end{array}$ \\
\hline 1 & January - March & Rp. 8,262 \\
2 & April - June & Rp. 8,692 \\
3 & July - September & Rp. 9,150 \\
4 & October - December & Rp. 9,650 \\
5 & January - March & Rp. 10,200 \\
\hline
\end{tabular}

Source: obtained from secondry data, 2019

The question is, please count the rate of sustainable strengthening from 1 to 5 quarter, and the average rate of strengthening over the past 5 quarters! The answer can be presented in table 2 below:

Table 2. Simulation Result on Strengthening Traditional Markets

\begin{tabular}{cccc}
\hline No. & Quarter (2018-2019) & Counting Prosess & $\begin{array}{c}\text { Strengt- } \\
\text { hening Rate }\end{array}$ \\
\hline 1 & April - June & $((8,692-8,262) / 8,262) \times 100 \%$ & $5.2 \%$ \\
2 & July - September & $((9,150-8,692) / 8,692) \times 100 \%$ & $5.3 \%$ \\
3 & October - December & $((9,650-9,150) / 9,150) \times 100 \%$ & $5.5 \%$ \\
4 & January - March & $((10,200-9,650) / 9,650) \times 100 \%$ & $5.7 \%$ \\
\hline
\end{tabular}

Source: obtained from secondry data, 2019

While the average level of strengthening can be counted as follows: $(5.2 \%+5.3 \%+5.5 \%+5.7 \%) / 4=5.4 \%$.

Table 2 shows that the rate of strengthening increased from quarter to quarter with an average increase of $5.4 \%$. This means that the efforts to strengthen the traditional markets can be declared successful. If so, the rate of welfare of traders in the traditional markets will 
increase and be evenly distributed.

Second, To find out whether the strengthening is sustainable or not (the score of $\mathrm{SSt}_{\mathrm{y}}$ goes up or down), use the formula below:

$-\mathrm{SSt}_{\mathrm{y}}=\left(\mathrm{R}_{\mathrm{y}}-\mathrm{R}_{\mathrm{y}-1} / \mathrm{R}_{\mathrm{y}-1}\right) \times 100 \%$

- $\mathrm{SSt}_{\mathrm{y}}=$ Sustainable strengthening in percentage (\%)

- $\mathrm{R}_{\mathrm{y}}=$ Market retribution revenue for one year

- $\mathrm{R}_{\mathrm{y}-1}=$ Market retribution revenue in the previous one year Simulation example:

The data example owned for the past 5 years, can be presented in table 3 below:

Table 3. Simulation Data on Market Retribution Revenue Per One Year

\begin{tabular}{ccc}
\hline No. & Year & $\begin{array}{c}\text { Market Retribution Revenue } \\
\text { (Million in IDR) }\end{array}$ \\
\hline 1 & 2014 & Rp. 7,262 \\
2 & 2015 & Rp. 7,692 \\
3 & 2016 & Rp. 8,150 \\
4 & 2017 & Rp. 8,650 \\
5 & 2018 & Rp. 9,190 \\
\hline
\end{tabular}

Source: obtained from secondry data, 2019

The question is, please count the rate of sustainability from 2014 to 2018, and the average rate of sustainability for 5 years! The answer can be presented in table 4 below:

\section{Table 4. Simulation Result on Sustainablity Rate of Strengthening Traditional Markets}

\begin{tabular}{cccc}
\hline No. & Year & Counting Prosess & $\begin{array}{c}\text { Sustainability } \\
\text { Rate }\end{array}$ \\
\hline 1 & 2015 & $((7,692-7,262) / 7,262) \times 100 \%$ & $5.9 \%$ \\
2 & 2016 & $((8,150-7,692) / 7,692) \times 100 \%$ & $6.0 \%$ \\
3 & 2017 & $((8,650-8,150) / 8,150) \times 100 \%$ & $6.1 \%$ \\
4 & 2018 & $((9,190-8,650) / 8,650) \times 100 \%$ & $6.2 \%$ \\
\hline \multicolumn{2}{l}{ Source: obtained from secondry data, 2019 }
\end{tabular}

While the average rate of sustainability can be counted as follows: $(5.9 \%+6.0 \%+6.1 \%+6.2 \%) / 4=6.1 \%$. 
Table 4 shows that the sustainability rate has increased from year to year with an average increase of $6.1 \%$. This means that the efforts to strengthen traditional markets can be declared sustainable. If so, the rate of comfort of the people shopping at the traditional market is increasing and evenly distributed.

Third, To find out whether the sustainable strengthening for tradisonal markets is consistent or not (the score of $\mathrm{CRR}_{2 \mathrm{y}}$ goes up or down), use the formula below:

- $\mathrm{CSSt}_{2 \mathrm{y}}=\left(\mathrm{R}_{2 \mathrm{y}}-\mathrm{R}_{2 \mathrm{y}-2} / \mathrm{R}_{2 \mathrm{t}-2}\right) \times 100 \%$

- $\mathrm{CSSt}_{2 \mathrm{y}}=$ Consistency of sustainable strengthening in percentage (\%)

- $\mathrm{R}_{2 \mathrm{y}}=$ Market retribution revenue for two years

$-\mathrm{R}_{2 \mathrm{y}-2}=$ Market retribution revenue in the previous two years Simulation example:

The data example owned for the past 10 years per every two years, can be presented in table 5 below:

Table 5. Simulation Data on Market Retribution Revenue Per Two Years

\begin{tabular}{ccc}
\hline No. & Year & $\begin{array}{c}\text { Market Retribution Revenue } \\
\text { (Million in IDR) }\end{array}$ \\
\hline 1 & $2010-2009$ & Rp. 15,262 \\
2 & $2012-2011$ & Rp. 15,692 \\
3 & $2014-2013$ & Rp. 16,150 \\
4 & $2015-2016$ & Rp. 16,650 \\
5 & $2017-2018$ & Rp. 17,190 \\
\hline
\end{tabular}

Source: obtained from secondry data, 2019

The question is, please count the rate of consistency for every two years from 2010 to 2018, and the average rate of consistency for 10 years from the previous two years to the next two years! The answer can be presented in table 6 below: 
Table 6. Simulation Result on Consistency of Sustainable Strengthening For Traditional Markets

\begin{tabular}{cccc}
\hline No. & Year & Counting Prosess & $\begin{array}{c}\text { Consistency } \\
\text { Rate }\end{array}$ \\
\hline 1 & $2012-2011$ & $((15,692-15,262) / 15,262) \times 100 \%$ & $2.8 \%$ \\
2 & $2014-2013$ & $((16,150-15,692) / 15,692) \times 100 \%$ & $2.9 \%$ \\
3 & $2015-2016$ & $((16,650-16,150) / 16,150) \times 100 \%$ & $3.1 \%$ \\
4 & $2017-2018$ & $((17,190-16,650) / 16,650) \times 100 \%$ & $3.2 \%$ \\
\hline
\end{tabular}

Source: obtained from secondry data, 2019

While the average rate of consistency can be counted as follows: $(2.8 \%+2.9 \%+3.1 \%+3.2 \%) / 4=3.0 \%$.

Table 6 shows that the rate of consistency increased from every two years before to the next two years for 10 years with an average increase of $3.0 \%$. This means that they efforts to strengthen traditional markets can be stated that they are consistently sustainable. If so, the model for strengthening traditional markets constructed has been proven to work well in estimating the results of efforts to strengthen traditional markets.

\section{Conclusion}

This research shows that (1) The modernization and technological development does not necessarily eliminate people's desire to shop in traditional markets, (2) The democratic trading model practiced in traditional markets can actually drive the people's economy, and (3) Innovation, partnership and policies developed in traditional markets can make them existing throughout time without compromising the needs of future generations. Referring to these things above, the model of strengthening traditional markets in the Bosowasi Region can be formulated for sustainable development in the era of the global economy. This model is called the BSWS Model.

Of course, formulating the model of strengthening traditional markets for sustainable development can not only be seen from three aspects as described above, but also must pay attention to many other aspects because these traditional markets show the social status of certain communities through activities carried out in the traditional markets. Here the research shows that the social 
structure in traditional markets in the Bosowasi Region appears as part of the cultural appropriations carried out by the people in the region.

Although this research has successfully demonstrated one model of strengthening traditional markets in the Bosowasi Region for sustainable development in the era of the global economy, but it cannot yet be shown how accurate the model works. It measn that it still needs to be tested how it works, whether it can be used or not in strengthening traditional markets sustainably in order to find out whether the people in the Bosowasi Region are responding to the strengthening efforts carried out or not. Therefore, further research is needed to prove how the formulated model works. 


\section{References}

Ajzen, I. (2002). Perceived behavioral control, self-efficacy, locus of control, and the theory of planned behavior. Journal of Applied Social Psychology, 32(4), 665-683. doi.org/10.1111/j. 1559-1816.2002.tb00236.

Ajzen, I. (2005), Attitudes, Personality and Behavior. 2nd Edition. McGraw-Hill Professional Publishing, Berkshire, GBR.

Aliyah, I. (2014). Penguatan Sinergi antara Pasar Tradisional dan Modern dalam Rangka Mewujudkan Pemerataan Pembangunan Ekonomi Kerakyatan. JA! UBL, 4(2), 22-31. Retrieved from http://jurnal.ubl.ac.id/index.php/ja/article/ view/531

Aliyah, I. (2017). Strategi Penguatan Peran Pasar Tradisional Sebagai Produk Budaya di Kota Surakarta. Cakra Wisata: Jurnal Pariwisata dan Budaya, 18(1), 1-15. Retrieved from https://jurnal.uns.ac.id/cakra-wisata/article/view/34371

Asribestari, R. and Setyono, J. S. (2013). Pengaruh Daya Tarik Pasar Tradisional dan Pasar Modern terhadap Preferensi Konsumen (Studi Komparasi Pasar Karangayu Dan Giant Superdome). Teknik PWK (Perencanaan Wilayah Kota), 2(3), 549-558. Retrieved from https://ejournal3.undip.ac.id/index. $\mathrm{php} / \mathrm{pwk} /$ article/view/2887

Berger, P. L. and Luckmann, T. (1966). The Social Construction of Reality: A Treatise in the Sociology of Knowledge. New York: Anchor Books.

Bintoro, R. W. (2010). Aspek Hukum Zonasi Pasar Tradisional dan Pasar Modern. Jurnal Dinamika Hukum, 10 (3), 349-363. doi: 10.20884/1.jdh.2010.10.3.105

Blau, P. (1977). A Macrosociological Theory of Social Structure. American Journal of Sociology, 83(1), 26-54. http://dx.doi. org/10.1086/226505

Cohen, B. J. (1992). Sosiologi Suatu Pengantar. Jakarta: Rineka Cipta.

Cristian, D et.al. (2015). The Components of Sustainable 
Development: A Possible Approach. Procedia Economicsand Finance, 26(15), 806-811. doi: 10.1016/S2212-5671(15)00849-7

Eshleman, J. R., and Barbara G. C. (1985). Sociology an Introduction. Toronto: Little Brown \& Company.

Farhani, I. and Sunaryo, B. (2014). Konsepsi Pengelolaan Berkelanjutan Pasar Apung Banjir Kanal Barat Kota Semarang. Ruang, 2(4), 341-350. Retrieved from https:// ejournal3. undip.ac.id/index.php/ruang/article/view/6509

Febrianty, D. (2013). Model Revitalisasi Pengelolaan Pasar Tradisional. Jurnal Sosial Ekonomi Pekerjaan Umum, 5(3), 175-186. Retrieved from http://jurnalsosekpu.pu.go.id/index. $\mathrm{php} /$ sosekpu/article/view/28

Fitdiarini, N.. (2015). Kepercayaan Pelanggan untuk Melakukan Online Shopping dan Dampaknya terhadap Minat Beli Ulang. Jurnal Ekonomi dan Bisnis Airlangga (JEBA) Journal of Economics and Business Airlangga, 25(3), 256-269. doi. org/10.20473/jeba. V25I32015.4339

Fitlayeni, R. et.al. (2015). Strategi Organisasi Informal Menjaga Persistensi Pasar Tradisional di Kecamatan Padang Barat. Mimbar: Jurnal Sosial dan Pembangunan, 31(1), 61-70. Retrieved from https://ejournal.unisba.ac.id/index.php/ mimbar/article/view/1106

Geertz, C. (1973). The Interpretation of Cultures. New York: Basic Book.

Habibah, T. P. Z. (2013). Identifikasi Penggunaan Formalin pada Ikan Asin dan Faktor Perilaku Penjual di Pasar Tradisional Kota Semarang. Unnes Journal of Public Health, 2(3), 1-10. doi.org/10.15294/ujph.v2i3.3031

Hamzah, A. et.al. (2008). Respon Komunitas Nelayan terhadap Modernisasi Perikanan (Studi Kasus Nelayan Suku Bajo di Desa Lagasa, Kabupaten Muna, Propinsi Sulawesi Tenggara). Sodality: Jurnal Sosiologi Pedesaan, 2(2), 191-208. doi. org/10.22500/sodality. v2i2.5885

Haris, R. (2018). Dinamika Kelompok Sosial Budaya di Kota 
Makassar: Memudarnya Stratifikasi Sosial Berbasis

Keturunan. Jurnal Masyarakat dan Budaya, 19(2), 189-202. doi.org/10.14203/jmb.v19i2.399

Henslin, J. M. (2006). Sosiologi dengan Pendekatan Mebumi, Edisi 6. Jakarta: Erlangga Lauer.

Johnson, D. P. (1986). Teori Sosiologi Klasik dan Modern. Terj. Jilid 1 -2. Jakarta: PT. Gramedia Indonesia.

Kamanto, Sunarto (2000). Pengantar Sosiologi. Jakarta: LPE-UI.

Karouw, Z. E. et.al. (2016). Faktor Penentu Pilihan Konsumen Komoditi Pertanian terhadap Tempat Berbelanja di Pasar Tradisional dan Pasar Modern di Kota Manado. AGRISOSIOEKONOMI, 12(1), 77-90. doi.org/10.35791/ agrsosek.12.1.2016.11401

Koentjaraningrat. (1988). Manusia dan Kebudayaan di Indonesia, Jakarta: Djambatan.

Kornblum, W. (2000). Sociology in a Changing World. Florida: Harcourt College Publisher.

Kupita, W. and Bintoro, R. W. (2012). Implementasi Kebijakan Zonasi Pasar Tradisional dan Pasar Modern (Studi di Kabupaten Purbalingga). Journal of Dinamika Hukum, 12(1), 45-59. doi.org/10.20884/1.jdh.2012.12.1.201

Landis,J.R.(1986). Sociology, Conceptsand Characteristics. California: Wadsworth Publishing Company.

Loomis, C. P. (1967). In Praise of Conflict and its Resolution. The American Sociological Review, 32(6), 875-890. doi: $10.2307 / 2092842$

Lufti, O. L. (2012). Dampak Keberadaan Indomaret terhadap Kondisi Sosial Ekonomi Pedagang Pasar Tradisional di Kelurahan Terjun Kecamatan Medan Marelan. Welfare State, 2(1), 1-11. Retrieved from https://jurnal.usu.ac.id/index. $\mathrm{php} / \mathrm{ws} /$ article/view/2131

Muksin, S. M. et.al. (2018). Pola Adaptasi Sosial Ekonomi Suku Bugis sebagai Pendatang di Desa Bobolio Kecamatan 
Wawonii Selatan. Jurnal Neo Societal, 3(1), 336-345. doi. org/10.33772/.v3i1.3576

Mustari, A. (2016). Perempuan dalam Struktur Sosial dan Kultur Hukum Bugis Makassar. $A l-' A d l$, 9(1). Retrieved from http:// ejournal.iainkendari.ac.id/al-adl/article/view/671

Noor, A. (2013). Perlindungan terhadap Pasar Tradisional di Tengah Ekspansi Pasar Ritel Modern. Economica: Jurnal Ekonomi Islam, 4(2), 107-120. doi.org/10.21580/ economica.2013. 4.2 .782

Noor, A. (2016). Pasar Tradisional dengan Penataan Modern di Kota Makassar, Economica: Jurnal Ekonomi Islam, 4(2), 1-10. doi.org/10.24252/nature.v4i1a2

Ogburn, W. F. (1922). Social Change with Respect to Culture and Original Nature. New York: B. W. Huebsch.

Parsons, T. (1939). The Professions and Social Structure. Social Forces, 17(4), 457-467. DOI: 10.2307/2570695

Radcliffe, B. and Reginald, A. (1940). On Social Structure. The Journal of the Royal Anthropological Institute of Great Britain and Ireland, 70(1), 1-11. Retrieved from http://links. jstor.org/sici ?sici=0307 $-3114 \% 281940 \% 2970 \% 3 \mathrm{~A} 1 \quad \% 3 \mathrm{C} 1$ \%3AOSS\%3E2.0.C0\%3B2-Y

Riki. (2019). Dampak Era Revolusi Teknologi Informasi dengan Industri Kreatif Digital Ala E-Commerce Tokopedia. Khazanah Ilmu Berazam, 2(1), 71-79. Retrieved from http://www.ejournal.ymbz.or.id/index.php/1/article/ view/68

Riyanti, P. (2013). Relasi Sosial Pedagang Etnis Cina dan Etnis Jawa di Pasar Tradisional. Komunitas: International Journal of Indonesian Society and Culture, 5(1), 53-63. doi. org/10.15294/komunitas.v5i1.2373

Robert. H. (1993). Perspektif tentang Perubahan Sosial. Jakarta: PT. Rhineka Cipta.

Roring, R. S. and Kusrini. (2017). Integrasi Sistem berbasis 
Predictive Analytics untuk Pasar Tradisional Indonesia. CSRID Journal, 9(1), 21-30. doi.org/10.22303/csrid.9.1.2017.21-30

Rustan, et.al. (2018). Adaptasi dan Perubahan Sosial Kehidupan Suku Bajo (Studi Kasus Suku Bajo Kelurahan Bajoe Kecamatan Tanete Riattang Timur Kabupaten Bone). Urban and Regional Studies Journal, 1(1), 31-37. Retrieved from https://postgraduate.universitas bosowa.ac.id/index.php/ursj/ article/view/60

Sabaruddin, S. S. (2016). Penguatan Diplomasi Ekonomi Indonesia Mendesain Clustering Tujuan Pasar Ekspor Indonesia: Pasar Tradisional vs Pasar Non-Tradisional." Jurnal Ilmiah Hubungan Internasional, 12(2), 205-219. org/10.26593/jihi. v12i2.2654.205-219

Saleha, Q. (2013). Kajian Struktur Sosial dalam Masyarakat Nelayan di Pesisir Kota Balikpapan. Buletin PSP, 21(1), 67-75. Retrieved from http://journal.ipb.ac.id/index.php /bulpsp/ article/view/7119

Sanderson. (2000). Sosiologi Macro, Sebuah Pendekatan Terhadap Realitas Sosial. Jakarta: PT RajaGrafindo Persada.

Seran, M. (2014). Perlindungan Hukum Bagi Pasar Tradisional di Era Globalisasi Dan Liberalisasi Perdagangan. MasalahMasalah Hukum. 43(3), 388-395. DOI: 10.14710/mmh. 43.3.2014.

Sihabudin, A. (2011). Komunikasi Antarbudaya: Suatu Perspektif Multidimensi. Jakarta: Bumi Aksara.

Sjafari, A. and Nugroho, K. S. (2011). Perubahan Sosial (Sebuah Bunga Rampai). Banten: FISIP UNITIRTA.

Smelser, N. J. (1981). Sociology. New Jersey: Prentice Hall Inc.

Soekanto, S. (1983). Beberapa Teori Sosiologi Tentang Struktur Sosial. Jakarta: CV. Rajawal.

Soemardjan, S. S. (1974). Setangkai Bunga Sosiologi. Jakarta: Lembaga Penerbitan UI.

Sulistyo, H. and Cahyono, B. (2010). Model Pengembangan Pasar 
Tradisional Menuju Pasar Sehat di Kota Semarang. Ekobis, 11(2), 516-526. doi.org/10.30659/ekobis.11.2

Supartiningsih. (2010). Konsep Ajjoareng-Joa' dalam Tatanan Sosial Masyarakat Bugis (Perspektif Filsafat Sosial). Jurnal Filsafat, 20(3), 217-238. doi.org/10.22146/jf.3420

Syani, Abdul. (1995). Sosiologi dan Perubahan Masyarakat, Bandung: Dunia Pustaka Jaya.

Tanguay, G. A. et.al. (2009). Measuring The Sustainability of Cities: A Survey based Analysis of The Use of Local Indicators, Cirano, 1-29. doi.org/10.2139/ssrn.1336649

Tanguay, G. A. et.al. (2009). Measuring the Sustainability of Cities:

A Survey-Based Analysis of the Use of Local Indicators. CIRANO - Scientific Publications No. 2009s-02, 1-29. doi.org/ 10.2139/ssrn.1336649

Utomo, T. J. (2011). Persaingan Bisnis Ritel: Tradisional Vs Modern. Fokus Ekonomi: Jurnal Ilmiah Ekonomi, 6(1), 122133. DOI: $10.34152 /$ fe.6.1.\%p

Wasilah, et.al. (2017). Perlindungan terhadap Pasar Tradisional di Tengah Ekspansi Pasar Ritel Modern. National Academic Journal of Architecture, 4(1), 107-120. doi.org/10.21580/ economica.2013.4.2.782

Werner, E. (1989). Cooperating Agents: A Unified Theory of Communication and Social Structure. Distributed Artificial Intelligence. Morgan Kaufmann, 1-39. Retrieved from https:// www.researchgate.net/publication/323194114_Cooperating_ Agents_A_Unified_Theory_of_Communication_and_Social_ Structure

Widiandra, et.al. (2013). Analisis Dampak Keberadaan Pasar Modern terhadap Keuntungan Usaha Pedagang Pasar Tradisional (Studi Kasus di Pasar Tradisional Kecamatan Banyumanik Kota Semarang). Diponegoro Journal of Economics, 2(10), 1-6. Retrieved from https://ejournal3. undip.ac.id/index.php/jme/article/view/1959

Wijayati, P. A. (2013). Model Pemberdayaan Pasar Tradisional 
Berbasis Ekonomi Kerakyatan di Kota Semarang. Paramita: Historical Studies Journal, 23(2), 167-178. doi.org/10.15294/ paramita.v23i2.2667

Yang, B. et.al. (2016). Analysis on Sustainable Urban Development Levels and Trends in China's Cities. Journal of Cleaner Production, 14(1), 1-24. DOI: 10.1016/j.jclepro.2016.09.121

Zeithaml, V. A. et.al. (2006). Services Marketing Integrating Customer Focus across the Firm. Boston, MA McGraw-Hill/Irwin. 